\title{
Mapping the Territory: a new direction for information literacy in the digital age
}

\section{Annamarie McKie}

University College for the Creative Arts, UK

\begin{abstract}
We can no longer assume that students arrive at university knowing what to read and knowing what standards are required of the material they do read (Brabazon,2008).
\end{abstract}

Evidence increasingly suggests that the information behaviours of students entering further and higher education have changed dramatically as a consequence of the internet. As learning developers in an HE art and design context, we are seeing many new students who exhibit an unfocused approach to research, bouncing from link to link with little analytical or critical thought. Such behaviour is leading to a growing lack of understanding concerning plagiarism and issues surrounding academic integrity. This in turn is having a significant effect on the quality of students' academic writing and is challenging the role academic libraries have traditionally played in the student experience.

This paper reflects on a research project called Mapping the Territory at the University for the Creative Arts. The project, which began in 2006, seeks to investigate a new pedagogy for information literacy. The project team has been looking at an integrated approach between librarians, study advisors and key academic staff in order to develop workshops that actively engage learners and help them to develop transferable skills in information literacy and information behaviour. Our research so far has focused on an extensive literature review exploring areas such as inquiry based learning, information behaviour, cognitivist theories and the nature of research in art and design. We have also conducted a series of focus groups at the Maidstone and Canterbury campuses, asking students about their experience of research and how such skills could relate to employability. A workshop 
model is being piloted where students have the opportunity to search for, select and begin to make use of information which is relevant to their field of enquiry. This model can be adapted to suit a range of disciplines and aims to start to embed research skills at an early stage with the hope of having a positive impact on student retention and employability.

Keywords: information behaviour; digital literacy skills; information literacy; academic integrity; Google generation; employability; research synthesis; inquiry based learning; critical analysis; lifelong learning; student retention

\section{Key competencies}

Information seeking is a key competency which any university student should acquire during undergraduate study and will be needed by young professionals as they embark on their careers (Debowski, 2003).

Increasingly students, including those in the non traditional disciplines of art and design, are treating their education as an investment. Research by Harbour (2005) suggests this may be due to the knock on effects of increased fees forcing students to work to support their studies. There is also increasing pressure from central government: In a recent interview for the Times Higher Education Supplement, Attwood (2008), reports John Denham (Secretary of State for Innovation, Universities and Skills) as saying 'The UK is 'not yet anywhere near' a position where employers believe that the university system is producing graduates with the skills they want. Denham suggests employers are looking for graduates who can solve problems, communicate, apply critical analysis to evidence and think for themselves. Such skills may well be 'taught' as part of a students' course, but they are often not documented in the course literature, with the result that the student may not perceive they are receiving this support; this is an area that could be greatly improved, particularly if $\mathrm{HE}$ institutions want to improve student retention.

Essentially, though, a new paradigm is forming and with it a new breed of learner. Behaviours exhibited by this group include increased selectivity in the lectures and workshops they attend, a need to know what skill they are going to acquire from the 
experience offered and more particularly, how relevant this may be to their course of study. The quality and accessibility of this information seems to be a key factor in student retention. The more relevant the students thought support was and the easier they found access to it, the less likely they were to consider dropping out. In the context of information literacy, this throws up many challenges, but shows the importance of contextualising sessions and collaborating with teaching staff and students to embed information literacy and behaviour as transferable skills. As Shenton and Jackson (2007) argue, 'If information literacy is not seen by learners as meaningful to them, they will not be motivated and are unlikely to make the effort to develop necessary concepts and skills'.

\section{Researchers of the future}

At the University for the Creative Arts, library and learning services have traditionally offered information literacy workshops that teach students how to 'source, navigate, select, retrieve, manipulate and manage information from a variety of sources' (HEA Employability Profile for Art and Design, 2007). Because of timetable constraints these sessions often focus on equipping students with a core set of library 'tools' at critical points in their course. These tools, which include key electronic resources, guides on referencing, plagiarism and lists of resources by subject area, are usually explored by the students during the session and are all located within a library web site. Attendance at these sessions varies by subject, but evaluations reveal that many students perceive themselves as expert searchers already, so may see little relevance in attending, especially when Google offers more instant satisfaction. There is an appreciation in the library sector that there are a specific set of information behaviours needed by the researcher of the future and that today's students think and process information fundamentally differently from their predecessors. A recent study commissioned by the British Library and JISC reveals young scholars who are 'horizontal' in their information seeking; bouncing, skimming, cutting and pasting their way through the internet: 
'Students usually approach their research without regard to the library's structure or the way that library segments different resources into different areas of its website' (CIBER/UCL,2008).

\section{Digital dissenters}

One could argue that many time-deprived students are more interested in 'quick wins' over the more considered and planned routes advocated in library sessions . Students may be proficient users of Facebook and Wikipedia, but do they know how to validate sources or how to formulate appropriate search terms. There is evidence from the Mapping the Territory project, that the internet can be quite confusing. One Canterbury student remarked:

'I waste a lot of time not knowing where to go...'.

These sort of questions are engaging a new school of 'digital dissenters', tired of the increasing plagiarism and the poor writing skills of their students. Tara Brabazon, Professor of Media Studies at the University of Brighton is currently leading this debate. In a recent inaugural lecture, she referred to Google as 'white bread for the mind' (filling,but not nutritious) and that it has 'dulled students' sense of curiosity and is stifling debate' (Frean,2008). Brabazon proposes a controversial new pedagogy for her first year students; she will not mark anything that does not come from a prescribed source she herself has checked. It seems that she is not interested in creating independent learners in the first year, but rather in what she refers to as an 'information scaffold'; guiding them through complicated ideas and introducing them to high quality materials. This would seem to follow Kolb's experiential cycle (Kolb \& Fry, 1975), that ideas are formed and re-formed through a cycle of experience. Interestingly Brabazon is not against internet sites, some of which she includes in the course reading. As she remarks:

'....if they don't know the names of the primary theorists, what are they going to put in the search engine?' (2008). 


\section{The nature of 'research' in art and design}

To add to this picture, there is the nature of 'research' in art and design itself. North (2005) suggests that there is a difference between studying subjects that deal with facts (hard) and those subjects that deal with concepts and opinions (soft). Students majoring in soft fields (art and design) are perhaps less likely to subscribe to beliefs in absolute knowledge. She cites research by Biglan (1973) in which he suggests 'the humanities... in contrast, tend to be...encouraging a view of knowledge as a matter of interpretation..'. This offers a new set of challenges for libraries, institutions founded after all to archive definitive, absolute content. It also has implications for the way we teach 'research' in the context of information literacy; we need to be less didactic and offer a more active, experiential style of workshop that perhaps mirrors a students' course learning experience. North (2005) goes on to say that: ' $\ldots$ arts students viewed essay writing (and getting supporting research) as problematic and time consuming ...'. However, qualitative research at UCA reveals students who may well be happy to undergo a similar sort of research process to support their studio practice. As one student at Canterbury remarked:

'I surf the net and click and save any pictures that appeal to me. These influence my work ...'

Library and Learning Services may be viewed as only offering support for essays and dissertations, and largely overlooked for studio research. This may well be because many students on art and design courses perceive themselves as 'makers' rather than 'academics' and do not always realise that the same research skills will also support their studio practice. If library workshops are perceived as only supporting an essay or dissertation, this of course has a direct impact on the use students make of the library services.

\section{Collaborative workshops}

A new style of information literacy workshop is beginning to emerge at the University for the Creative Arts which draws on some of the research outlined in this paper. 
Using theories of cognitivist and experiential learning, academic liaison librarians have linked up with key academic tutors and Study Advisors, to devise a more collaborative (rather than didactic) style of research workshop, specific to art and design. The 90 minute sessions, which are facilitated by an Academic Liaison Librarian and a Study Advisor, can accommodate a variety of learning styles including collective working, modelling and hands on experience, even a blend of all three. For example, the workshop at the Maidstone campus offers students the opportunity to 'research' in a group and then present their findings to their tutor in the style of the 'studio crit' thus receiving feedback on their research sources. One of the key outcomes (taken from the CILIP definition of information literacy) is to engage students in the 'importance of knowing when and why you need information, where to find it and how to evaluate, use and communicate it...'

In this flexible model, students work through a set of 'information scaffolds' in research including being able to identify a topic of interest, information searching and retrieval, evaluation, critical analysis, interpretation and research synthesis. These concepts could also be contextualised in their course lectures and seminars. We propose that the skills taught here could be viewed as a transferable skill in information literacy, as defined by CILIP (above). The workshops are 'mapped' into Year One and Year Two of a BA course, so that by their final year, a student could have developed a 'portfolio' of information behaviours that considerably enhance their potential as an active researcher in art and design. The 'information scaffolds' in more detail are as follows:

\section{Being able to identify a topic of interest}

This involves students developing skills in using the library catalogue to locate sources and receiving study advice on analysing the essay question, note taking and generating key words. Carefully mirroring the interpretative nature of 'research' in art and design, students are encouraged to brainstorm and 'mind map', initially getting down on paper what they already know about a subject and using this as a starting point for an initial search. They then ask questions of the sources they encounter, such as 'who, why, what, where, when or how?' (e.g. 'Who are the key contributors to this discussion?). There is strong emphasis on keeping this interactive overview 
active throughout their research and using a variety of sources including books and journal articles.

\section{Information searching and retrieval}

This is an activity-focused session on locating and evaluating academic sources in art and design (comparisons are made between using library electronic sources and Google). Guidance and activities are centred around constructing online search queries using key words (formed from their initial engagement with key theorists and locating their field of enquiry. There is strong emphasis on retrieving relevant and focused information and in particular the possibility of downloading journal articles in pdf format from locations off campus. However, students are also encouraged to access books and journal articles held in the library and to use indexes and bibliographies to build up a research portfolio.

\section{Evaluation}

Sometimes an academic tutor joins the session and there are group discussions on evaluating sources. Most importantly here, new students begin to learn good information habits, such as questioning the source and asking whether the authors are respected or whether the information is biased. Library guides are given out on validating your sources including warnings about over reliance on internet sources.

\section{Critical analysis}

Skills in sifting through research to select the information that will be most useful for an essay or dissertation are modelled. Students ask themselves how does this new information fit in with what I already know? How can I link together all this information in a new and original way? Can I now identify things I do not know and ways to find them out? Study Guides are given out to support this.

\section{Interpretation}

This part of the session is focused on the importance of finding your own voice, writing in your own words and developing an argument. An activity is centred round plagiarism and how to use evidence to support an argument and how to cite 
references and format a bibliography using the Harvard Referencing System as recommended by UCA. Accompanying handouts may be given on reading and notetaking. The importance of organising your research material and keeping track of its provenance is stressed.

\section{Research synthesis}

Study advice tips are given via handouts and demonstrations. This part of the session concentrates on structuring and writing the essay or dissertation. Emphasis is placed on developing an argument and the importance of organising your notes to try and locate evidence to support each step in your argument. Information on academic writing styles and methodology may be introduced and advice is given on the time management and organisational skills necessary to support in the production of a piece of academic writing.

\section{Conclusions}

Our research at the University for the Creative Arts has revealed significant skills gaps in students new to $\mathrm{HE}$, particularly regarding their online information behaviours. Our surveys reveal that 'Google generation' students may well perceive themselves to be expert searchers when in reality, they are unable to construct focused search queries and spend very little time in evaluating information, for relevance, accuracy or authority. This has far reaching implications not only for the standard of written work handed in, but also for the ways that students access and use information in libraries. Many academics are concerned with the cut and paste mentality of their students and the rise of plagiarism. The academic library should be the hub of learning in any higher education institution. Its main purpose is to support the teaching, learning and research functions of a university, but librarians and study advisors also offer vital expertise in educating researchers to be information literate and independent learners. Since this is a transferable skill that can be linked to employability, we need to work on promoting these skills to students and academic staff so that they can see the relevance to learning and teaching. Evidence from employers themselves, suggests that they are not seeing very well equipped 
graduates; many lack the skills employers need, such as being able to think for themselves and apply critical analysis to evidence.

The challenge we face is being able to offer these skills in a format that fits in with the busy lifestyles of students in higher education (a recent lifestyle survey for the THES (Sodexo, 2008) reveals 33\% of full time students are in part time work and $48 \%$ of students study outside lectures and seminars for 2-3 hours per day. We also need to be more in tune with students' digital habits and behaviours. According to the same lifestyle survey (above), 88\% of students use social networking sites like Bebo and Facebook every week. Based on this picture, library services need to provide more flexible, customisable, innovative information skills units, that can also be offered online and which are embedded into course learning units such as VLEs. This is a key deliverable of the INHALE informs project at the University of Huddersfield (Inhale, 2008). One way of doing this is to develop learning objects (podcasts, videos, interactive tutorials, etc) that students can dip in and out of, on key aspects of the information environment. At the University for the Creative Arts, the Information Literacy sub group is currently developing such a learning object on managing and citing references. There are also some comparable learning objects in the sector, such as Imperial College's ‘Olivia' module (Imperial, 2007) and Birkbeck's LIBLOIL (Birkbeck, 2008).

Our recommendations from the research so far are as follows:

- Information literacy workshops should incorporate a variety of active learning techniques in order to engage the learner.

- These workshops should be complemented by learning objects on key aspects of information literacy (i.e. referencing, using secondary sources, writing literature reviews).

- All information skills resources should be embedded within course modules (i.e. VLEs).

- The link between information literacy and employability should be defined in course documentation.

- Librarians need to develop and promote their expertise in information literacy.

- Libraries need to consider the motivations of their users and make information literacy both timely and relevant to learners. 
- Librarians need to take advantage of the exciting opportunities e-learning offers; the key to success is to get out of the library and build partnerships with learning technologists, teachers and study advisers.

It is hoped that the next stages of the research will be to link up with key practitioners in this area and explore further links with employability and student retention.

If you would like to find out more about this project, or make some suggestions, please contact Annamarie McKie at amckie@ucreative.ac.uk

\section{References}

Attwood, Rebecca. (2008) Skills gap still a concern, UUK told.

http://www.timeshighereducation.co.uk/story.asp?sectioncode=26\&storycode $=4$ $\underline{03495}$ (21 September 2008)

Biglan, A. (1973) 'The characteristics of subject matter in different academic areas'. Journal of Applied Psychology, 57 (3), pp 195-203.

Brabazon, Tara. (2006) 'The Google effect: Googling,blogging, wikis and the flattening of expertise'. Libri, 56 (3), pp167-167

Brabazon, Tara. (2008) The University of Google; education in the post information age. London: Ashgate Publishing.

Birkbeck, University of London. (2008) LIBLOIL (Library Learning Objects for Information Literacy) ONLINE: http://www.bbk.ac.uk/lib/life/skills/ (accessed 28 October 2008).

Chartered Instititute of Library and Information Professionals. (2008) Information Literacy group. Definition of Information Literacy. ONLINE: http://www.cilip.org.uk/policyadvocacy/informationliteracy/definition/default.htm (accessed 5 October 2008) 
Debowski, Shelda. (2003) 'Information seeking: building effective information users in tertiary settings'. In Partners in Learning. Proceedings of the 12th Annual Teaching Learning Forum. 11-12 February 2003.Perth: Edith Cowan University.

Frean, Alexandra. (2008). White bread for young minds, says University of Brighton professor. ONLINE :

http://technology.timesonline.co.uk/tol/news/tech and web/the web/article3182 091.ece (accessed 15th March 2008)

Griffiths, Linda. (2007) Student focus group at Canterbury campus. University for the Creative Arts. 10 October 2007.

Harbour, Sophie. (2005) 'Employability issues for fine art educators'.

Art Design \& Communication in Higher Education. Vol 4, Number 2, pp 121.134

Higher Education Academy. (2007) Student employability profile for art and design. ONLINE:

http://www.heacademy.ac.uk/assets/York/documents/ourwork/tla/employability/ student employability profiles art and design.pdf (accessed 31st October 2008)

Information for Nursing and Health in an Information Environment. (2007). Aims and objectives of the Inhale Project Team ONLINE:

http://inhale.hud.ac.uk/inhale/ (accessed 5 October 2008) University of Huddersfield

Kitchen, Rachel. (2008). Student Focus Group at Maidstone campus, University for the Creative Arts. 5 March 2008. 
Kolb. D. A. and Fry, R. (1975) 'Toward an applied theory of experiential learning;, in C. Cooper (ed.) Theories of Group Process, London: John Wiley.

North, Sally. (2005) 'Different values, different skills? A comparison of essay writing by students from arts and science backgrounds'. Studies in Higher Education, Vol 30(6), pp 85-102

Prensky, Marc. (2001) 'Digital Natives, Digital Immigrants'. On the Horizon,(MCB University Press) Vol 9, No 5, pp 1-6

Shenton, A.K and Jackson, M. (2007) 'Information Literacy teaching and information behaviour'. Library and Information Update, Chartered Institute of Library and Information Professionals.

Sodexo. (2008) University Lifestyle Survey. http://www.uk.sodexo.com/uken/Images/ULS\%20Summary\%202008 tcm15185165.pdf> (published in THES 21 September 2008)

University College London (UCL) CIBER group.(2008) Information behaviour of the researcher of the future. London: University College London. CIBER Briefing paper; 9.

\section{Author details}

Annamarie McKie is College Librarian/Assistant Director of Library and Learning Centres (Kent) at the University for the Creative Arts. 